\title{
The Effect of Psychological Capital and Emotional Labor on Job Performance: A Study on Five Star Hotel Enterprises in Antalya
}

\author{
Neslihan Kan Sönmez 1 (1)
}

\begin{abstract}
Service quality and customer satisfaction, which are basic goals of hotel enterprises, can be achieved by the high job performance of qualified staff. The focal point of this study was the key role that psychological capital and emotional labor play in high job performance. In this study, which aimed to determine the effect of psychological capital and emotional labor on job performance, the sample group consisted of 400 personnel employed by 16 five-star hotel enterprises operating in the centre of Antalya, specifically in the districts of Kemer and Alanya. The data collected by questionnaire technique were analysed by statistical techniques, such as frequency and percentage distribution, arithmetic mean, standard deviation, Pearson's correlation analysis, multiple linear regression analysis, independent samples t-test, and one-way analysis of variance. What is more, a factor analysis was administered for validity and reliability, and Cronbach's Alpha coefficients were calculated. Obtained data suggested that the psychological capital levels of employees were positive above the medium level. The general emotional labor performance of employees was at the medium level. The job performance levels perceived by employees were high. As a result of the correlation analysis performed in the study, positive correlations were identified between psychological capital and emotional labor at $r=0.529$, psychological capital and job performance at $r=0.717$, and emotional labor and job performance at $r=0.595$. The regression analysis showed that one unit of change in the psychological capital caused an increase of 0.543 on the job performance, and a change of one unit in the psychological capital resulted in an increase of 0.712 on the job performance. In addition, according to the t-test and variance analysis results, while psychological capital, emotional labor, and job performance did not differ significantly according to gender, marital status, age, or education level, psychological capital levels of the hotel employees differed significantly according to their departments, and emotional labor performance differed significantly in line with their departments and working durations.
\end{abstract}

\section{Keywords}

Psychological Capital, Emotional Labor, Job Performance, Hotel Enterprises

\section{Introduction}

The rising importance of tourism in the economic growth of a country necessitates tourism employees from the sector to show their best performance at all times. Since hotel employees constitute the largest labor force component in tourism services, their performance have a sig- 
nificant effect on the service quality and satisfaction perceptions of national and international tourists. In recent years, the emotional labor shown by employees during their work, which is considered a closely related concept for employees to achieve the desired performance so that enterprises can obtain a sustainable competitive advantage, is discussed (Miranda \& Godwin, 2018; Begenirbaş \& Çalışkan, 2014; Hochschild, 1983/2012; Grandey, 2000). In addition to physical and mental contributions of employees, enterprises expect them to show emotions in line with the emotional display rules specified by the enterprises (Sohn \& Lee, 2012).

According to Hochschild (1983/2012), who was the first to discuss emotional labor comprehensively, emotional labor is a process for employees to manage their emotions during guest interaction so that they comply with organizational expectation. The basis of emotional labor is the necessity to show the required effort at the workplace in order to create appropriate impressions and establish neutral and positive communication with others (Wharton \& Erickson,1993). The obligation of employees to display emotions complying with the emotional rules specified by enterprises increases service quality and customer satisfaction but may affect employees negatively due to possible emotional problems (Bickes, Yılmaz, Demirtaş, \& Uğur, 2014). Employees' negative emotions decrease positive organizational outcomes, such as job performance, job satisfaction, and organizational commitment, and increased negative consequences, such as organizational stress, intentions to quit, organizational alienation, and burnout (Aslan \& Büyükbeşe, 2019; Tokmak, 2014; Scott \& Barnes, 2011). It is of importance to increase the psychological capital of employees in order to prevent negative consequences that are likely to occur based on emotional labor (Büyükbeşe \& Aslan, 2019; Özyılmaz Misican \& Türkoğlu, 2019). Investigated as a concept focusing on revealing and developing individuals' existing abilities and characteristics in terms of organizational behaviour, psychological capital (Seligman \& Csikszentmihalyi, 2000) suggests that personal negativities, such as weakness, incompetence, and defects, have a positive equivalence and can be developed (Demir \& Şen Demir, 2019).

Related literature suggests that psychological capital and emotional labor are important prerequisites of job performance (Miranda \& Godwin 2018; Nasurdin, Ling \& Sabrina, 2018; Begenirbaş \& Çalışkan, 2014; Hochschild, 1983/2012; Shahnawaz \& Jafri, 2009; Grandey, 2000). In tourism literature, however, there are few studies on the relationship between psychological capital and emotional labor with job performance (Çolak, 2018; Nasurdin, et al., 2018; Kızanıklı \& Çöp, 2017; Eşitti, 2015; Dönmez, 2014; Karatepe, 2014; Ünlü \& Yürür, 2011). In studies carried out on tourism enterprises, it can be seen that psychological capital has an effect on organizational behaviour fields, such as job satisfaction, organizational commitment, organizational citizenship behaviour, organizational identification, worklife quality, job burnout, individual innovativeness, and career adaptability (Demir \& Şen Demir, 2019; Safavi \& Bouzari, 2019; Suna \& Okun, 2019; Kodaş, 2018; Kumlu \& Güçlü Nergiz, 2018; Kim, Perrewe, Kim, \& Kim, 2017; Jung \& Yoon, 2015; Paek, Schuckert, Kim, 
\& Lee, 2015; Lin, 2013). The studies conducted in the tourism enterprises on emotional labor behaviours showed that emotional labor affected job satisfaction, service quality, intentions to quit, organizational citizenship behaviour, and emotional burnout (Genç \& Gümüş, 2017; Kim, et al., 2017; Kaplan \& Ulutaş, 2016; Yakar, 2015; Pala \& Tepeci, 2014; Lu, Shih, \& Chen, 2013). As there are relatively fewer studies on the effects of both variables on job performance, this study aimed to determine the effects of psychological capital and emotional labor on job performance regarding employees of five-star hotel enterprises. What is more, psychological capital, emotional labor, and job performance were compared according to the demographic characteristics of the employees.

\section{Conceptual Framework}

\section{Emotional Labor}

Used first by Hochschild (1983) in his book named The Managed Heart, the term emotional labor (Shapoval, 2019) is considered a key subject today in organizational studies (Gabriel \& Diefendorff, 2015). It is described by Hochschild (1983/2012) as the management of facial and body expressions by employees when they serve customers. Hochschild (1983/2012) regards emotional labor as a service delivery stage. In this stage, service is considered a "show," a service employee "an actor," a customer "an audience," and service delivery "an act" of a play (Chu \& Murrmann, 2006). The communication between the actors and the audience is based on the form of the show, which is organized in line with organizational norms and rules and their individual perceptions (Duran \& Gümüş, 2013).

Brotheridge \& Grandey (2002) divide emotional labor into two categories: the first of these categories emphasizes the feature of work, and the second one focuses on the emotion management process of employees. The first is called "work-focused emotional labor," consisting of the frequency, duration, and diversity of the emotional labor. The second is named "employee-focused emotional labor," which is an emotion management technique used by employees during their communication with customers. This category covers surface acting and deep acting (Ko \& Jeng, 2016). Most of the literature on emotional labor in the service sector has discussed these two kinds of acting. Surface acting consists of a simulation or effort to manage the expressions and gestures that have emotional meaning in front of clients and other collaborators. In this regard, the emotions expressed do not match those genuinely felt and are designed to follow the emotional rules determined by the enterprise. Deep acting, however, means a mental effort aiming to change real emotions in order to express the emotions specified by the enterprise. The third strategy, natural and genuine acting, is when the emotions needed by an enterprise are felt by the employee and occur spontaneously (Humphrey, Ashforth, \& Diefendorff, 2015). This third form was discussed in few empirical studies 
(Santos \& Fontenelle, 2019). Surface and deep acting have been exemplified by Grandey (2000) as follows: surface acting, reflecting that desired emotions are not real, is like an artificial smile on the face of an employee while they are indeed sad and angry. Deep acting is the effort of an employee to change the emotions they consider improper before a guest with their own positive emotions. For example, an employee begins to feel bored at the end of a long shift. This employee may think about some positive events (an approaching holiday or going out with friends) in their life during a service delivery. The service provider tries to feel the real emotion in the emotion they show towards a guest. Therefore, although that emotion is real, it is not related to that guest (Shapoval, 2019).

Grandley \& Gabriel (2015), researchers studying this subject, have defined a theoretical perspective which is determinant in understanding emotional labor. This perspective refers to harmony between an employee and a job; in other words, it focuses on an employee who has characteristics, such as extroversion, positive effectiveness, and emotional management skills, that are appropriate to the emotional needs of the job. This perspective asserts that employees complying with the job most should show less emotional labor. Such congruence between person-work and person-organization is of importance for functions requiring direct contact with guests, especially because employee perceptions fit their jobs and organizational values. Often, it serves as the definers of their performance. Therefore, it is important to analyse and select employees who can adapt to the job more properly; thus, deep acting may occur with little effort (Dahiya, 2017).

When employees' deep acting is performed with more effort in an enterprise, positive organizational outcomes, such as job performance, job satisfaction, and organizational commitment, decrease and negative consequences, such as organizational stress, intentions to quit, organizational alienation, and burnout, increase (Aslan \& Büyükbeşe, 2019; Tokmak, 2014; Scott \& Barnes, 2011). It is of importance to increase the psychological capital of employees in order to prevent such negative events that are likely to occur based on emotional labor (Büyükbeşe \& Aslan, 2019; Özyılmaz Misican \& Türkoğlu, 2019). Psychological capital can direct the actions and attitudes of employees thanks to its regulatory role in the building of their emotions (Tüzün, Çetin, \& Basım, 2014). Psychological capital affects the cognitive processes of employees. Accordingly, the positive attitudes and actions that employees may have with psychological capital will trigger the positive power they need for the rights they can achieve (Hur, Rhee, \& Ahn, 2016).

\section{Psychological Capital}

Psychological capital answers the questions of "who you are" and "what you can be" and is different from human capital (what you know), social capital (who you know), and financial capital (what you have) (Luthans, Luthans, \& Luthans, 2004). Luthans, Norman, Avolio, \& 
Avey (2008) argue that human capital is your present knowledge, thought, skill, experience, and education while social capital covers the norms and communication networks that allow joint cooperation, and financial capital refers to your concrete assets with material value. The indicators representing psychological capital are self-efficacy, hope, optimism, and resilience (Luthans, Youssef, \& Avolio, 2007). Self-efficacy is the emotion individuals feel towards themselves regarding whether they can do a job successfully or not. The belief of individuals with high self-efficacy for overcoming difficult duties is higher (Bouzari \& Karatepe, 2016). Hope is the will needed for achieving goals and is a road map for reaching these goals. Hopeful individuals determine certain goals and find roads going to desired goals; hope activates these paths (Avey, Luthans, \& Youssef, 2010). Optimism is a term referring to feelings and thoughts of individuals related to future expectations. Optimistic individuals are those who are more satisfied, have higher morale and expectations, have positive goals, do not give up in the face of difficulties, and can become more motivated to achieve any given task (Hirlak, Taşliyan, \& Sezer, 2017). Resilience is the ability to show a positive change and development against negative events, such as uncertainty and failure. Individuals with high resilience can cope with new and difficult conditions effectively, can generate alternative ideas and thoughts, and can adapt to new circumstances (Altunkol, 2011). These personality variables, constituting psychological capital, ensure higher job performance and higher quality service in today's competitive working environment.

Psychological capital is being examined as a concept focused on revealing and improving the potentially strong abilities and characteristics of individuals in terms of positive organizational behaviour (Seligman \& Csikszentmihalyi, 2000). The concept suggests that personal negativities, such as weakness, incompetence, and defects, have a positive equivalence and can be developed (Demir \& Şen Demir, 2019). Luthans' model (Psychological Capital Intervention) determined that individuals' psychological capital levels could be developed in a group training provided in almost three hours. In this benefit analysis made, the investment made on psychological capital provided a $270 \%$ increase. In this respect, psychological capital has a structure, which can be developed regarding the increase in job performance (Luthans, Avey, Avolio, Norman, \& Combs, 2006).

\section{Job Performance}

Related literature suggests that psychological capital and emotional labor are important prerequisites of job performance. These two variables are emphasized as effective tools in increasing job performance (Miranda \& Godwin 2018; Nasurdin, et al., 2018; Begenirbaş \& Çalışkan, 2014; Hochschild, 1983/2012; Shahnawaz \& Jafri, 2009; Grandey, 2000). Munchinsky (2003) argued that job performance is a set of actions that can measure, monitor, and evaluate employees' success (Almutairi, Moradi, Idrus, Emami, \& Alanazi, 2013). Murphy (1989) defined job performance as fulfilling the responsibility of a certain task, which covers 
familiar factors, such as time, speed, and efficiency (Zeb, Abdullah, Bin Othayman, \& Ali, 2019). George \& Jones (2005) argue that performance level is an evaluation of the results of an individual's job actions. This refers to the determination of the extent an individual shows a good or bad performance in achieving a task (Rezaee, Khoshsima, Zare Bahtash, \& Sarani, 2018). Borman \& Motowidlo (1993) urged that performance had two dimensions: task performance and contextual performance; Task performance includes the activities anticipated in the role that employees perform for a wage. Contextual performance refers to the tasks beyond a role's definition for employees (Nasurdin et al., 2018). When a receptionist, working at the front office department, carries out a check-in operation for a guest who wants to stay at the hotel, this action refers to task performance. On the other hand, when the same receptionist helps his/her workmates or guests beyond his/her responsibilities, this is associated with contextual performance.

\section{Literature Review}

In tourism literature, there are few studies on the relationship among the psychological capital and emotional labor in relation to job performance (Çolak, 2018; Nasurdin, et al., 2018; Kızanıklı \& Çöp, 2017; Eşitti, 2015; Dönmez, 2014; Karatepe, 2014; Ünlü \& Yürür, 2011). Kızanıklı \& Çöp (2017) investigated the relationship between positive psychological capital and job performance perception. According to the research results collected from 280 employees working at 5 stars hotel enterprises operating in Istanbul, there was a very strong positive relationship between both the positive psychological capital and its sub-dimensions and job performance perception. In addition, while the effect levels of self-efficacy, optimism, and hope were close to each other in explaining job performance, the effect level of psychological resilience was less. In the study carried out by Nasurdin, et al. (2018) at private hospitals operating in the medical sector, the researchers reported that while the self-efficacy, hope, and optimism dimensions of psychological capital had a positive effect on job performance, the dimension of resilience did not have a positive impact. The lower effect of resilience on job performance than other components of psychological capital, which was concluded in both studies, may be explained by not providing sufficient managerial support to develop positive coping skills by granting employee-controlled authority when faced with a significant difficulty or a risk in the enterprise. What is more, an investigation was carried out by Dönmez (2014) on 602 employees in the travel industry. The investigation found that the positive psychological capital had a positive and significant relationship with affective well-being, job satisfaction, employee performance, and life satisfaction. In the study conducted by Karatepe (2014) at hotel enterprises, it was concluded that the job involvement had a mediating effect regarding the effect of the dimension of hope of the psychological capital on job performances and service improvement performances of employees.

In another study performed by Çolak (2018) on 400 cabin attendants at an airline en- 
terprise, it was concluded that the emotional labor of the cabin attendants had a positive and significant effect on their performances. In the research carried out by Ünlü \& Yürür on 214 employees working at tourism and health institutions operating in Yalova, the relationship among emotional labor and emotional exhaustion with task and contextual performance was examined. This study determined that the deep acting from the sub-dimensions of the emotional labor increased the intentions to show task and contextual performance. Eşitti (2015) conducted an investigation on 320 employees working at accommodation establishments operating in the province of İzmir in order to determine the effect of emotional labor on job performance. This study concluded that the emotional labor level had no effect on the job performances of employees.

In addition, studies have been conducted on this subject in different fields. The results of the study performed by Saithong-in (2016) on 102 sworn financial advisors in Thailand determined that the psychological capital dimension of resilience had a positive effect on job performance. The study carried out by Sun, Zhao, Yang, \& Fan (2012) on approximately 733 nurses working at five university hospitals in Heilongjiang, China determined that higher psychological capital improved the job performance, both directly and through job engagement. In their study on 179 employees working at a large financial service institution operating in the north-eastern US, Peterson, Luthans, Avolio, Walumbwa, \& Zhang (2011) determined that the psychological capital of employees changed over time. Also, in the study, it was determined that a one-unit increase (or decrease) in the psychological capital of the employees caused a one-unit increase (or decrease) in the performance of the employees. The investigation carried out by Erkuş \& Afacan Fındıklı (2013) on 572 employees working in different occupational groups found a positive and significant relationship between psychological capital and job performance. In the analyses made regarding the sub-dimensions, the factors of hope and resilience were found to have positive effects on the job performance.

Begenirbaş \& Çalışkan (2014) conducted research on 403 employees working in the private sector in Ankara to specify the relationship between emotional labor and job performance. In this study, it was concluded that while there was a negative relationship between surface acting and job performance, a positive and significant relationship was found among job performance and both deep acting and genuine acting. Çağlıyan, Fındık, \& Doğanalp (2013) concluded in their study on 128 health personnel working at a health institution operating in Konya province that there was a negative relationship among surface acting with task performance and contextual performance. In addition, in this study, a positive relationship was determined among genuine acting and contextual performance. In their study carried out on 377 employees in the call centres of two large financial institutions operating in Australia, Goodwin, Groth, \& Frenkel (2011) stated that the surface acting had a direct relationship with employee turnover and emotional burnout. Also, in this study, the relationship between surface acting and job performance was indirect through the mediation of emotional burnout. 
There are also many studies discussing the relationships among psychological capital with other factors in the tourism literature. In the study conducted by Çelik \& Bilginer (2018), Yücel (2019) on the relationship between the psychological capital and job satisfaction at hotel enterprises, it was concluded that there was a positive relationship with psychological capital along with its sub dimensions and job satisfaction. In the study carried out by Jung \& Yoon (2015) at deluxe hotel enterprises, they determined that there was a positive relationship among the psychological capital dimensions of hope and optimism with job satisfaction. Also, in this study, it was concluded that a positive relationship among the psychological capital dimensions of hope and resilience and organizational citizenship behaviour. In the investigations performed by Kumlu \& Güçlü Nergiz (2018) and Kodaş (2018), a positive and strong relationship was found between psychological capital and organizational citizenship behaviour. In the studies conducted on hotel enterprises, Demir \& Şen Demir (2019) found a positive relationship between psychological capital and organizational identification. Suna \& Okun (2019) determined a positive relationship between the psychological capital and personal innovativeness. Safavi \& Bouzari (2019) identified a significant relationship between psychological capital and career adaptability. Kim, et al. (2017) determined that psychological capital increased the quality of job life and service improvement behaviour at hotel enterprises. In the study performed by Kodaş (2018) at hotel enterprises, a significant and negative relationship was detected between the psychological capital and job stress. In the study conducted by Lin (2013) on hotel employees, it was concluded that psychological capital had a strong and negative effect on job burnout. Paek, et al. (2015) determined that front office employees with high-level psychological capital had more job engagement.

Within the framework of the literature on emotional labor, psychological capital, and job performance presented above, the basic hypotheses of this study, aiming to determine the effect of psychological capital and emotional labor on job performance in five-star hotel enterprise employees, are as follows:

Hypothesis 1: Psychological capital has a significant and positive effect on job performance.

Hypothesis 1a: Self-efficacy has a significant and positive effect on job performance.

Hypothesis 1b: Hope has a significant and positive effect on job performance.

Hypothesis 1c: Resilience has a significant and positive effect on job performance.

Hypothesis 1d: Optimism has a significant and positive effect on job performance.

Hypothesis 2: Emotional labor has a significant and positive effect on job performance.

Hypothesis 2a: Surface acting has a significant and positive effect on job performance.

Hypothesis 2b: Deep acting has a significant and positive effect on job performance. 
Hypothesis 2c: Natural acting has a significant and positive effect on job performance.

\section{Method}

The data of this study were obtained by a questionnaire with four parts. The questionnaire was conducted in June, July, August, September, and October 2019. In the first part of the questionnaire, the demographic characteristics (gender, marital status, age, education level, department, working time in the tourism sector) were included. In the second part, a psychological capital scale developed by Luthans, et al. (2007) and translated into Turkish by Erkuş \& Afacan Fındıklı (2013), consisting of four dimensions (self-efficacy, hope, resilience and optimism) and 24 items, was administrated. In the psychological capital scale, the self-efficacy dimension can be exemplified by the item "I feel confident while contributing to discussions about the strategy and objectives of the enterprise where I work," and the dimension of hope may be exemplified by the item "I can find many ways to achieve my goals regarding my current job." The item "I can overcome difficulties in my workplace thanks to my previous experience" may be given as an example for the dimension of resilience, and the optimism dimension may be exemplified by the item "I always try to see the glass half-full regarding my job." In the third part, a scale developed by Diefendorff, Croyle, \& Gosserand (2005) and adapted into the Turkish language by Basım \& Begenirbaş (2012), including three dimensions (surface acting, deep acting, natural acting) and 14 items, was administered in order to determine the emotional labor behaviours of employees. In the emotional labor scale, the item "I act to show the emotions my job requires" may be provided as an example for the surface acting dimension, and the dimension of deep acting may be exemplified by the item "I try to experience a behaviour I have to show a customer" whereas the item " the emotions I show to customers are real" may be given as an example for the natural acting dimension. Each item in the scales of psychological capital and emotional labor was designed in Likert type and rated as follows: " $1=$ Strongly Disagree," "2=Disagree," " $3=$ Agree in Medium Level," "4=Agree," and " $5=$ Completely Agree." In the fourth part, a scale developed by Borman \& Motowidlo (1993) and adapted into the Turkish Language by Karakurum (2005), consisting of two dimensions (contextual performance, task performance) and 24 items, was used. Regarding the job performance scale, while the task performance may be exemplified by the item "I consider my professional knowledge to be sufficient," the item "I believe that I work in harmony and cooperation with my co-workers" may be given as an example for the contextual performance dimension. Each item in the job performance scale was rated in Likert type as follows: "1=Very low," "2=Low," " $3=$ Medium," " $4=$ High," and " $5=$ Very high."

The population of this study comprised of the employees of all five-star hotel enterprises operating in Antalya, an important tourism destination in Turkey. A certain sample was taken due to the limitations, such as time and cost. A cluster sampling method was used, and hotel enterprises were considered as a cluster. In this regard, the administration was executed in 16 
five-star hotel enterprises operating in the centre of Antalya and the districts of Kemer and Alanya with participation of the questionnaire being voluntary for this study. The formula of $\mathrm{n}=\mathrm{s}^{2} \mathrm{Z} \alpha^{2} / \mathrm{d}^{2}$, recommended by Özdamar (2001) for large populations $(\mathrm{N}=10,000)$, was used in order to specify sample size. The parameters in the formula were determined as a result of previous studies and a pilot application of 35 people. In this regard, $Z_{0.05}=1.96$ and a sampling error, showing effect size, was accepted to $b e \mathrm{~d}=0.1$ for standard deviation $\mathrm{s}=1$ significance level $\alpha=0.05$, and a minimum sample size was calculated to be 384 after these values were written in the aforementioned formula. In this respect, considering that there might be incorrect, inaccurate, incomplete, and low reliable papers, 525 questionnaires were distributed, and 413 of them were returned with 400 of them being assessed.

The demographic characteristics of the employees were given with frequency and percentage distributions. In addition, mean and standard deviation values for the scale and its dimensions were taken. In order to determine the relationships among the psychological capital, emotional labor, and job performance, a Pearson correlation analysis was administrated while the effect of psychological capital and emotional labor on job performance was specified through multiple linear regression analysis. As the data showed normal distribution in the comparison of psychological capital, emotional labor, and job performance according to the demographic characteristics of the subjects, independent samples t-test and one-way analysis of variance (one way ANOVA) were utilised for independent samples. The factor analysis was carried out for the construct validity of the scales used in the study, and Cronbach's Alpha coefficients were calculated for the reliability of these scales. SPSS for Windows program was used in the data analysis.

\section{Results}

The distribution of 400 employees according to the demographic characteristics are provided in Table $1.37 .8 \%$ of the subjects were female. $62.2 \%$ of them were male. $44.3 \%$ of them were married. $55.7 \%$ of them were single. $68.8 \%$ of them were under the age of 35 , and $59.8 \%$ of them graduated from secondary education. It was found out that while $6 \%$ of the subjects worked in the front office department, $28 \%$ in food and beverage department, $17.8 \%$ in housekeeping department, $14.7 \%$ in kitchen, and 33.5\% in other departments, $56.3 \%$ of them worked in the tourism sectors for 8 years and less. 
Table 1

Distribution of the Subject according to Their Demographic Characteristics

\begin{tabular}{|c|c|c|c|}
\hline Variables & Groups & $\mathbf{n}$ & $\%$ \\
\hline \multirow{2}{*}{ Gencer } & Female & 151 & 37.8 \\
\hline & Male & 249 & 62.2 \\
\hline \multirow{3}{*}{ Marital status } & Married & 177 & 44.3 \\
\hline & Single & 223 & 55.7 \\
\hline & 25 and below & 123 & 30.8 \\
\hline \multirow{2}{*}{ Age } & 26-35 & 152 & 38.0 \\
\hline & $36-45$ & 93 & 23.3 \\
\hline \multirow{5}{*}{ Education level } & 46 and above & 32 & 8.0 \\
\hline & Primary School & 49 & 12.2 \\
\hline & Secondary School & 239 & 59.8 \\
\hline & Higher Education & 112 & 28.0 \\
\hline & Front Office & 24 & 6.0 \\
\hline \multirow{3}{*}{ Department } & Food and Beverage & 112 & 28.0 \\
\hline & Housekeeping & 71 & 17.8 \\
\hline & Kitchen & 59 & 14.7 \\
\hline \multirow{5}{*}{ Working Duration } & Other & 134 & 33.5 \\
\hline & 3 years and below & 52 & 13.0 \\
\hline & 4-8 years & 173 & 43.3 \\
\hline & 9-13 years & 123 & 30.8 \\
\hline & 14 years and above & 52 & 13.0 \\
\hline Total & & 400 & 100.0 \\
\hline
\end{tabular}

Cronbach's Alpha coefficients on the factor analysis performed regarding the constructed validity of the scales used in the research and some descriptive statistics are provided in Table 2. Bartlett's tests and KMO values urged that the factor analysis could be applied for three scales, and the sample size was a sufficient size (KMO $>0.70$; Bartlett's Test; $\mathrm{P}<0.001)$. When examining the factor analysis results, it was seen that the psychological capital scale had 4 factors explaining $62.713 \%$ of the total variance, the emotional labor scale consisted of 3 factors explaining $60.942 \%$ of the total variance, and the job performance scale included 2 factors explaining $59.610 \%$ of the total variance. Cronbach's Alpha coefficients of the psychological capital, emotional labor, and job performance scales were calculated to be $0.878,0.856$, and 0.837 , respectively. When examining the arithmetic mean values, it was a medium value in the Likert type rating above 3 , for general psychological capital $(\mathrm{X}=3.86)$. While the "self-efficacy" was determined to be the sub-dimension with the highest mean (X $=4.12$ ), the sub-dimension of "optimism" was found to have the lowest mean value ( $\bar{X}=3.60)$. The mean value of general emotional labor behaviour of the employees of the hotel enterprises was concluded to be $\bar{X}=3.18$. While the sub-dimension of the "surface acting" had the lowest mean value $(X=2.95)$, the sub-dimension of "natural acting" was found to have the highest mean value $(\bar{X}=3.51)$. On the other hand, the average job performance of employees was calculated to be $\bar{X}=4.08$. However, the contextual performance levels $(X=4.11)$ of the employees were identified to be higher than the task performance levels $(X=3.92)$ despite being close to each other. 
Table 2

Validity and Reliability Results of the Scales and Some Descriptive Statistics

\begin{tabular}{|c|c|c|c|c|c|c|}
\hline $\begin{array}{l}\text { Dimensions - Factors } \\
\text { / Scales }\end{array}$ & $\begin{array}{c}\text { Number of } \\
\text { Items }\end{array}$ & $\begin{array}{l}\text { Eigenva- } \\
\text { lues }\end{array}$ & $\begin{array}{c}\text { Explained } \\
\text { Variance } \%\end{array}$ & $\begin{array}{c}\text { Cronbach's } \\
\text { Alpha }\end{array}$ & $\operatorname{Mean} \bar{X}$ & SD \\
\hline Self-efficacy & 6 & 5.313 & 22.139 & 0.824 & 4.12 & 0.75 \\
\hline Hope & 6 & 3.951 & 16.463 & 0.832 & 4.02 & 0.70 \\
\hline Resilience & 6 & 3.024 & 12.600 & 0.856 & 3.71 & 0.60 \\
\hline Optimism & 6 & 2.763 & 11.511 & 0.811 & 3.60 & 0.58 \\
\hline Physchological Capital & 24 & - & 62.713 & 0.878 & 3.86 & 0.58 \\
\hline Surface Acting & 7 & 8.526 & 38.754 & 0.833 & 2.95 & 0.83 \\
\hline Deep Acting & 4 & 3.332 & 15.146 & 0.798 & 3.35 & 0.84 \\
\hline Natural Acting & 3 & 1.549 & 7.042 & 0.724 & 3.51 & 0.81 \\
\hline Emotional Labor & 14 & - & 60.942 & 0.856 & 3.18 & 0.76 \\
\hline $\begin{array}{l}\text { Contextual Perfor- } \\
\text { mance }\end{array}$ & 20 & 7.011 & 46.739 & 0.812 & 4.11 & 0.75 \\
\hline Task Performance & 4 & 1.931 & 12.871 & 0.778 & 3.92 & 0.91 \\
\hline Job Performance & 24 & & 59.610 & 0.837 & 4.08 & 0.73 \\
\hline \multicolumn{7}{|c|}{ Kaiser-Meyer-Olkin $(K M O)=0.897 ; \quad$ Bartlett's Test: $\chi 2=3542.6 ; P<0,001$ (for psychological capital scale) } \\
\hline \multicolumn{7}{|c|}{ Kaiser-Meyer-Olkin $($ KMO $)=0.828 ;$ Bartlett's Test: $\chi^{2}=3223.1 ; P<0,001$ (for emotional labor scale) } \\
\hline \multicolumn{7}{|c|}{ Kaiser-Meyer-Olkin $(K M O)=0.878 ;$ Bartlett's Test: $\chi^{2}=3482.4 ; P<0,001$ (for job performance scale) } \\
\hline
\end{tabular}

The Pearson correlation analysis results conducted to determine the relationships among the psychological capital, emotional labor, and job performance are provided in Table 3. When examining these results, it was observed that there were significant and positive relationships between all variables. The correlation coefficients showed that there were significant, positive, and strong relationships between general job performance and general psychological capital $(\mathrm{r}=0.717)$ and between general emotional labor and general job performance $(\mathrm{r}=0.695)$. In addition, a significant, positive and intermediate relationship was determined between general psychological capital and general emotional labor $(\mathrm{r}=0.529)$. It was also concluded that the correlations among psychological capital dimensions and job performance were close to each other but the "surface acting" from the emotional labor dimensions affected the job performance less than other dimensions $(\mathrm{r}=0.408)$.

The results of the multiple linear regression analysis related to the effect of psychological capital and emotional labor on job performance are provided in Table 4. When examining these results, it is seen that the multiple linear regression analysis is significant $(\mathrm{F}=124.553$; $\mathrm{P}<0.01)$. What is more, the regression coefficients for psychological capital and emotional labor variables were also found to be significant $(\mathrm{P}<0.01)$. In Table 4, the determination coefficient was calculated to be $\mathrm{R}^{2}=0.487$, this value shows that $48.7 \%$ of the changes in the job performance of employees were explained by the variables of psychological capital and emotional labor. 
Table 3

Correlation Coefficients for Relationships between Variables

\begin{tabular}{|c|c|c|c|c|c|c|c|}
\hline Variables & $\begin{array}{c}\text { Surface } \\
\text { Acting }\end{array}$ & $\begin{array}{c}\text { Deep } \\
\text { Acting }\end{array}$ & $\begin{array}{c}\text { Natural } \\
\text { Acting }\end{array}$ & $\begin{array}{c}\text { Emotional } \\
\text { Labor }\end{array}$ & $\begin{array}{c}\text { Con- } \\
\text { textual } \\
\text { Perfor- } \\
\text { mance }\end{array}$ & $\begin{array}{l}\text { Task Per- } \\
\text { formance }\end{array}$ & $\begin{array}{c}\text { Job } \\
\text { Perfor- } \\
\text { mance }\end{array}$ \\
\hline Self-efficacy & $0.231^{* *}$ & $0.285^{* *}$ & $0.336^{* *}$ & $0.280^{* *}$ & $0.493^{* *}$ & $0.219^{* *}$ & $0.558^{* *}$ \\
\hline Hope & $0.343^{* *}$ & $0.397^{* *}$ & $0.437^{* *}$ & $0.409^{* *}$ & $0.556^{* *}$ & $0.343 * *$ & $0.643^{* *}$ \\
\hline Resilience & $0.494^{* *}$ & $0.507^{* *}$ & $0.573^{* *}$ & $0.567^{* *}$ & $0.535^{* *}$ & $0.520^{* *}$ & $0.665^{* *}$ \\
\hline Optimism & $0.617^{* *}$ & $0.569^{* *}$ & $0.658^{* *}$ & $0.681^{* *}$ & $0.470^{* *}$ & $0.641^{* *}$ & $0.634^{* *}$ \\
\hline $\begin{array}{l}\text { Physchological } \\
\text { Capital }\end{array}$ & $0.453^{* *}$ & $0.479^{* *}$ & $0.553^{* *}$ & $0.529^{* *}$ & $0.608^{* *}$ & $0.462^{* *}$ & $0.717^{* *}$ \\
\hline Surface acting & - & $0.767^{* *}$ & $0.743^{* *}$ & $0.911^{* *}$ & $0.397^{* *}$ & $0.317^{* *}$ & $0.408^{* *}$ \\
\hline Deep acting & $0.767^{* *}$ & - & $0.807^{* *}$ & $0.883^{* *}$ & $0.552^{* *}$ & $0.768^{* *}$ & $0.646^{* *}$ \\
\hline Natural acting & $0.743^{* *}$ & $0.807^{* *}$ & - & $0.826^{* *}$ & $0.552^{* *}$ & $0.595^{* *}$ & $0.630^{* *}$ \\
\hline Emotional labor & $0.911^{* *}$ & $0.883^{* *}$ & $0.826^{* *}$ & - & $0.579^{* *}$ & $0.876^{* *}$ & $0.695^{* *}$ \\
\hline
\end{tabular}

${ }^{* *} P<0,01$

Table 4

Multiple Linear Regression Analysis Results

\begin{tabular}{lccccc}
\hline Model & $\boldsymbol{\beta}$ & $\mathbf{S E}$ & $\mathbf{t}$ & $\mathbf{P}$ & ANOVA \\
\hline Constant & 1.007 & 0.206 & 4.890 & $0.000^{* *}$ & $\mathrm{~F}=124.553$ \\
Psychological capital & 0.712 & 0.054 & 11.522 & $0.000^{* *}$ & $\mathrm{P}=0.000^{* *}$ \\
Emotional labor & 0.543 & 0.039 & 9.759 & $0.000^{* *}$ &
\end{tabular}

** $P<0.01 ;$ Dependent Variable: Job Performance; $R^{2}=0.487$

The multiple linear regression model regarding the effect of the variables of psychological capital (PC) and emotional labor (EL), independent variables, on job performance (JP), the dependent variable, is as follows:

Multiple Linear Regression Model: $J P=1.007+0.712 . P C+0.543 . E L$

When this model is examined, it is seen that one unit of change in psychological capital will cause an increase of 0.712 units on job performance, and a change of one unit in emotional labor will result in an increase of 0.543 units on job performance.

The results of t-test and variance analysis, administrated for comparing psychological capital, emotional labor, and job performance according to the demographic characteristics of the subjects, are provided in Table 5. When examining these results, it is observed that psychological capital, emotional labor, and job performance did not show a significant difference according to gender, marital status, age, and education level $(\mathrm{P}>0.05)$. According to Table 5, the psychological capital levels of the employees showed a significant difference in accordance with their departments $(\mathrm{P}<0.05)$. When considering the arithmetic mean values, the psychological capital levels of the employees working in the kitchen department ( $\bar{X}$ $=3.69$ ) were determined to be lower compared to other departments. On the other hand, it was detected that the emotional labor behaviours of employees differed significantly according 
to department and working durations $(\mathrm{P}<0.05)$. The mean values showed that the group with the highest emotional labor behaviour was the front office department $(\bar{X}=3.40)$ while the groups with the lowest emotional labor behaviour were housekeeping $(\bar{X}=3.05)$ and kitchen ( $X=2.95$ ) departments. It was also found out that the employees working in the tourism sector for 0-3 years had the highest emotional labor behaviour ( $X=3.48)$ while those working in the tourism sector for 14 and more years showed the lowest emotional labor behaviour $(\bar{X}=2.92)$.

Table 5

Comparison of the Psychological Capital, Emotional Labor and Job Performance by Demographic Characteristics of the Subjects

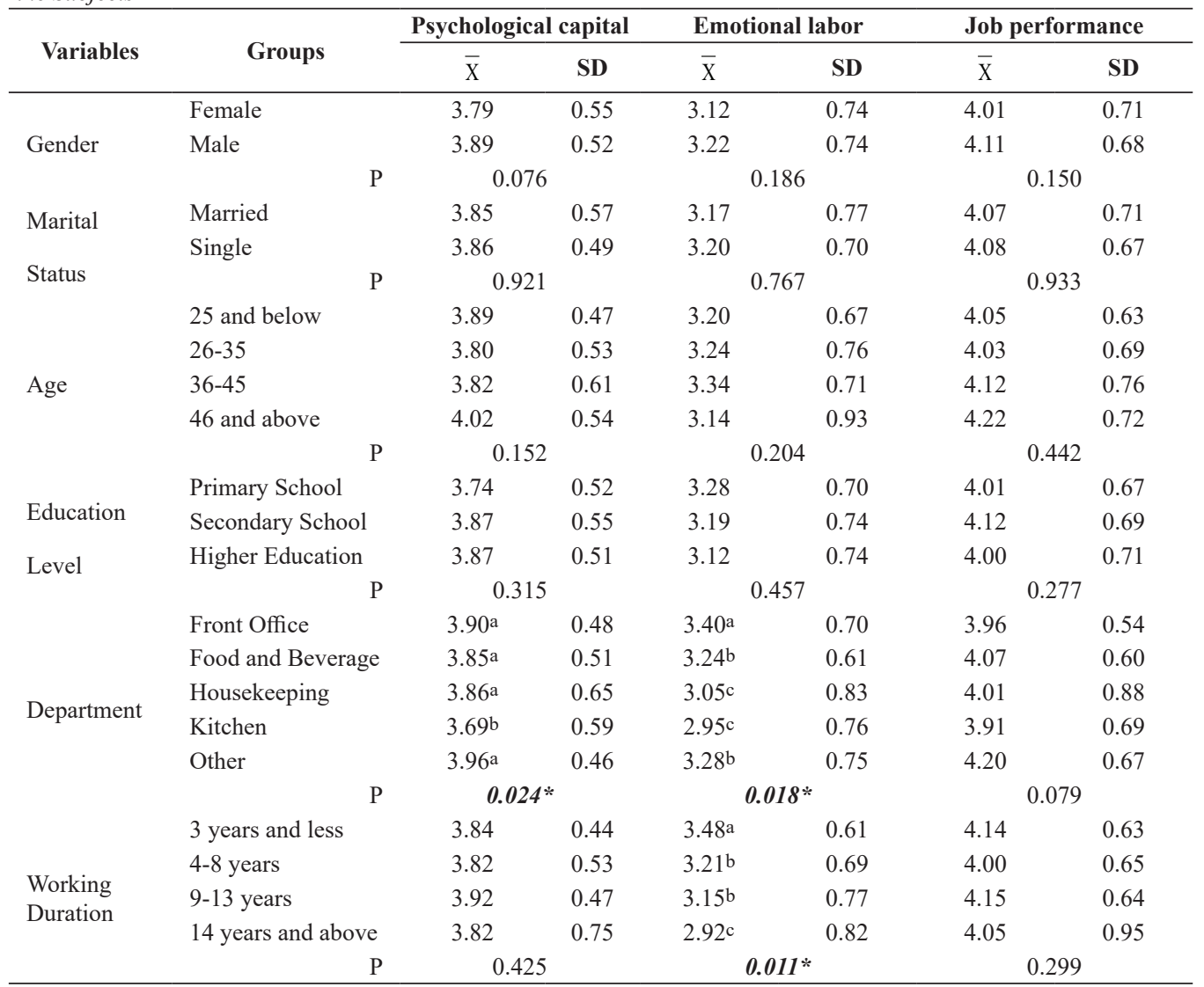

${ }^{*} P<0.05$ a,b,c: Different letters within columns show statistical difference between groups

\section{Discussion and Conclusion}

It was aimed to determine the effect of psychological capital and emotional labor on the job performance in this study, to which 400 personnel employed by 16 five-star hotel enterprises operating in the centre of Antalya and the districts of Kemer and Alanya participated. 
In this research, it has been concluded that general psychological capital levels of the employees have been positive above medium level, and while the most positive dimension was self-efficacy, the least positive dimension was optimism. Similarly, there are many studies urging that the psychological capital levels of hotel employees are high (Suna \& Okun, 2019; Yücel, 2019; Çelik \& Bilginer, 2018; Kumlu \& Güçlü Nergiz, 2018; Yorulmaz \& Yavan, 2018; Kaya, Atabay, \& Alamur, 2017). As the employees show higher job performance when self-efficacy, the most positive dimension in the hotel enterprises, increases (Luthans $\&$ Yousseff, 2007), employing those with high self-efficacy is needed to increase job performance. As the employees with high self-efficacy are persistent and success-oriented against the difficulties they face (Shahnawaz \& Jafri, 2009) and have higher self-belief in fulfilling a job successfully (Bouzari \& Karatepe, 2016), these features increase the ambition and determination of these employees and provide higher performance formation (Kurt, 2012). As optimism, the most negative dimension at the hotel enterprises compared to other dimensions, can be learned and developed just like helplessness, subjecting this skill in training programs will increase the performance of employees (Seligman, 2011).

In the research, it was found that the general emotional labor behaviours of the employees were at intermediate level, and while the surface acting was determined to be the dimension with most negative views, the most positive dimension was identified to be natural acting. In a similar vein, the studies by Karakaş (2017), Demirel (2015), and Lu et al. (2013) determined that the emotional labor behaviours of employees at hotel enterprises were in the intermediate level. Wen, Huang, \& Hou (2019) concluded that the emotional labor behaviour levels of hotel employees were low. Acting mostly by genuine acting in hotel enterprises shows that the employees usually do not need to pretended his / her behaviour at work and can display the emotions that s/he really feels. In other words, there is no difference between the emotions a hotel enterprise employee feels and the emotions his/her job requires. This will decrease the stress level, which is one of the negative situations that a hotel employee is likely to experience (Grandey, 2000). Therefore, the job performance of an employee providing more quality service will increase (Begenirbaş \& Çalışkan, 2014). The reason of showing less surface acting may be due to the fact that the employees changing the emotions they actually feel to express the emotions desired by the hotel enterprise requires more intensive mental effort and the negative events that the employee may experience in psychological respect.

As a result of the correlation analysis conducted to determine the relationship between emotional labor and job performance, it was identified that there was a significant and positive relationship between emotional labor and job performance. The conclusion obtained in this study shows that as emotional labor increases, job performance will increase highly. In this regard, it can be said that emotional labor is the determinant factor of job performance. Similarly, in the studies conducted by Giardini \& Frese (2006) and Tsai (2001), emotional labor has been described as one of the fundamental determiners of a series of organizational 
conclusions covering guest relationships and employee performance. The emotional labor of employees was argued to be an important factor for a successful job performance by Robbins \& Judge (2013). The findings of some studies on the relationship between emotional labor and job performance (Çolak, 2018; Ünlü \& Yürür, 2011) confirm this result achieved in this study. In the research conducted by Çolak (2018) at an airline enterprise, it was concluded that the emotional labor competences of the cabin attendants affected their performances positively. Moreover, the investigation carried out by Ünlü \& Yürür (2011) in tourism and health institutions suggested that the deep acting, a sub-dimension of emotional labor, increased the intention to show job performance. On the other hand, in the study conducted by Eşitti (2015) at accommodation enterprises, it was identified that emotional labor level had no effect on the job performance of employees. In this study, it was also determined that surface acting, from the sub-dimensions of the emotional labor, affected job performance less (positively) compared to deep acting and natural acting. It is possible to explain this result with both biological and psychological pressure created by surface acting on employees. As a matter of fact, Grandey (2000) also stated that surface acting displayed may have an effect on decreasing job performance (Grandey, 2000). Although it is urged in the related literature that emotional labor is an important prerequisite for job performance and this variable can be used as an effective tool in increasing job performance (Çolak, 2018; Miranda \& Godwin 2018; Robbins \& Judge, 2013; Hochschild, 1983/2012; Ünlü \& Yürür, 2011; Giardini \& Frese, 2006; Tsai 2001; Grandey, 2000), it is also discussed that employees may have emotional disharmony or emotional exhaustion after a while if they show an intense effort to act in accordance with the emotional behaviour rules required by the job by displaying ostensible emotional behaviours that are disconnected from their real feelings during work processes or by suppressing their real feelings. It is emphasized that showing artificial feelings in relationships with customers, in other words, masking his/her own feelings, may prevent an employee from acting according to his/her own feelings at work (Bolton, 2005). This may be indicated as a negative aspect of emotional labor for employees. In this regard, it has been revealed by a large number of research findings that job performance is affected by negative situations, such as increase in job stress, burnout level, and leave of employment intention (Akdu \& Akdu, 2016; Çelik \& Yıldız, 2016; Yücebalkan \& Karasakal, 2016; Eroğlu 2014; Scott \& Barnes, 2011; Oral \& Köse, 2011; Furnell 2008; Grandey, 2003; Brotheridge \& Grandey, 2002; Pugliesi, 1999).

Multiple linear regression analysis results of the study showed that psychological capital is more effective on the job performance than emotional labor. The lower effect of emotional labor on job performance than psychological capital can be explained by the fact that while the job performance of employees is affected positively when they intentionally display positive emotions towards customers (Goodwin, et al., 2011; Grandey, Fisk, Mattila, Jansen, $\&$ Sideman, 2005), their job performance decreases, (Goodwin, et al., 2011; Tice \& Brats- 
lavsky, 2000) and their job stress, burnout, and leave of employment intention increase when they have to show the actions instructed by enterprises to show for customers, by acting or masking their real feelings (Akdu \& Akdu, 2016; Çelik \& Yıldız, 2016; Scott \& Barnes, 2011; Furnell, 2008; Grandey, 2003; Pugliesi, 1999). In line with this finding, increasing the psychological capital level of employees is necessary to encourage job performance increase. Firstly, hotel managers may consider self-efficacy, hope, optimism, and resilience, which are components of psychological capital, as these affect the job performance positively in their recruitment process. They may prefer individuals wishing to work in hotel enterprises and who have higher scores of psychological capital components, which is consistent with Rich (1999). Human resources departments can assess the psychological capital level of job candidates as part of standard written tests (Hur et al., 2016). Other than that, strategies to develop these psychological capacities can be suggested. In order to develop self-efficacy, training programs and indirect modelling, in which participants can observe and model others in their respective fields, can be used (Luthans, et al., 2004). Observing others who have become successful with sustained effort and seeing that it takes effort for success will urge the participants to think that they have the capacity of becoming successful (Nasurdin, et al., 2018). As hotel employees face the difficulty of attaching and meeting the requests of guests, they should attend training programs designed by hotel enterprises to develop their competences, knowledge, skills, and abilities. In this regard, their self-efficacy will increase, and this increased self-efficacy will instil confidence in employees in their abilities to overcome difficulties and negative conditions, achieve goals, and maintain a positive state of mind (Wang, Mei, $\&$ Zhu, 2017) and will finally result in better performance. What is more, as the successful experiences of employees increase their self-efficacy (Bandura, 1997), it may be suggested to divide difficult and complex tasks into smaller pieces in order to increase the experience of managers and employees and then to teach them one by one (Luthans, et al., 2006). When employees become successful in dealing with such little pieces, they will feel the required self-efficacy in themselves, and this positive result will reflect in their job performance. As the physiological and psychological well-being of an individual affects his/her self-efficacy, health programs, aid packages, and a positive and supportive organizational culture provided by hotel enterprises will affect the self-efficacy of employees positively. Setting specific and challenging goals in order to increase hope, developing emergency planning in order to achieve goals, and redefining goals, when necessary, in order to avoid false hopes may help hotel employees to enrich their hope level. (Luthans, et al., 2006). Another strategy to enrich the hope level of hotel employees is to include them in decision processes by providing them with more autonomy and to apply an effective training and award system. Based on the recommendation made by Luthans, et al. (2008), optimism may be reinforced with mentorship and training programs in which the following issues will be learnt: (a) diagnose and identify the beliefs that restrain you when faced with difficulties, (b) evaluate these beliefs, and (c) replace these beliefs with more constructive ones (Nasurdin, et al., 2018). Resilience may be 
supported by establishing a professional network providing hotel employees with easy guidance and social support when necessary (Jackson, Firtko, \& Edenborough, 2007). Another strategy urged by Hodges, Keeley, \& Grier (2005) argues that managers will increase the resilience level of their employees when they acknowledge the achievements of their employees and appreciate them in this regard.

This study has also detected that there is a positive and intermediate relationship between the emotional labor and the psychological capital. The theory of positive emotions confirms this result. In the theory of positive emotions, in which the relationship between the emotional labor and the psychological capital is established (Fredrickson, 2001), it has been observed that employees with higher psychological capital are working at more appropriate mental and emotional levels in an organisational environment (Fredrickson \& Losada, 2005). This may suggest that the dimensions of psychological capital may affect the emotions of employees in the job environment. In a similar vein, the affective events theory (Weiss \& Cropanzano, 1996) argues that the effects created by past events on the psychological events (psychological capital dimensions) of individuals cause some emotional reactions in working life. In addition, the conclusion obtained in this study in this respect is in accordance with the results achieved in prior studies conducted on emotional labor and psychological capital (Fredrickson, 2001; Fredrickson \& Losada, 2005; Hur et al., 2016). When considering the positive results related to emotional labor, such as high performance, high service quality, and high customer satisfaction in hotel enterprises, it is of importance to provide employees, serving as frontline tourism professionals, with the required psychological capital.

It has been determined in this study that psychological capital, emotional labor and job performance did not differ significantly according to gender, marital status, age, and education level. It has been concluded that while the psychological capital levels of the employees have differed significantly according to the departments, the emotional labor acts have differed significantly in line with the departments and working durations. In this regard, the psychological capital levels of employees working in the kitchen department were found to be lower compared to other employees working in other departments. Focusing on revealing and developing the present abilities and characteristics of the employees working in the kitchen department by hotel management (Seligman \& Csikszentmihalyi, 2000) will contribute to increasing the psychological capital of employees. In addition, being aware of the fact that the employees' personal negativities, such as weakness, incompetence, and defects, have a positive equivalence and can be developed (Demir \& Şen Demir, 2019); thus, acting in line with this awareness will contribute to increasing the psychological capital of employees. What is more, it has been determined that employees in the front office department show higher emotional labor behaviour and the level of displaying emotional labor behaviour decreases as the working time in the sector increases. As the employees in the front office department are in communication with guests more during their reservation, check-in, accommodation, and 
check-out processes, they can be said to show higher emotional labor behaviour to fulfil their job properly. It can be stated that as working duration increases, the employees, strengthening their position in the hotel enterprise thanks to the professional experience and competence they have gained, show less emotional labor behaviour.

When considering the conclusions obtained in the study, it is seen that psychological capital is of importance in carrying the performance to a superior level in hotel enterprises. According to the conclusions of the research, emotional labor is an important prerequisite for job performance. Many studies in the related literature confirm this conclusion (Çolak, 2018; Miranda \& Godwin 2018; Robbins \& Judge, 2013; Hochschild, 1983/2012; Ünlü \& Yürür, 2011; Giardini \& Frese, 2006; Tsai 2001; Grandey, 2000). In addition, it should not be overlooked that when employees show an intense effort to display emotions in accordance with the emotion display rules determined by the enterprise, they may have emotional disharmony or emotional exhaustion after a while. This may be indicated as a negative aspect of emotional labor for employees. In this regard, it has been supported by a large number of research findings that job performance is affected by negative situations, such as increase in job stress, burnout level, and leave of employment intention (Akdu \& Akdu, 2016; Çelik \& Yıldız, 2016; Yücebalkan \& Karasakal, 2016; Eroğlu 2014; Scott \& Barnes, 2011; Oral \& Köse, 2011; Furnell 2008; Grandey, 2003; Brotheridge \& Grandey, 2002; Pugliesi, 1999).

The result of this study should be interpreted based on three limitations. Firstly, the use of self-report measures of job performance may result in a bias regarding conclusions. To minimize this potential issue, future researchers (such as managers and colleagues) can collect job performance data from more than one source. Secondly, this research can be generalized for the enterprises in the service sector and is limited to an administration to be carried out in 5 -star hotel enterprises operating in Antalya Province. Future studies may be conducted by using the enterprises in different sectors in their sample groups. Thirdly, in this investigation, the effect of the emotional labor and psychological capital on job performance has been studied. Investigation of the relationships among these two variables and terms such as organizational health, organizational fit, organizational climate, conflict management, business profitability and efficiency will both contribute to the related literature and will become an important data source for those concerned. 


\section{References}

Akdu, U., \& Akdu, S. (2016). Duygusal emek ve iş stresinin tükenmişlik üzerindeki etkileri: Profesyonel turist rehberleri üzerinde bir araştırma [Effects on burnout of emotıonal labor and job stress: A research on professional tourist guides]. Uluslararası Sosyal Araştırmalar Dergisi, 9(47), 1142-1153. http://dx.doi.org/10.17719/jisr.2016.1460

Almutairi, D. O., Moradi, E., Idrus, D., Emami, R., \& Alanazi, T. R. (2013). Job satisfaction and job performance: A case study of five-star hotels in Riyadh, Saudi Arabia, World Journal of Social Sciences, 3(1), 27-37.

Altunkol, F. (2011). Üniversite öğrencilerinin bilişsel esneklik algılanan stres düzeyleri arasındaki ilişkinin incelenmesi. (Yüksek Lisans Tezi). Çukurova Üniversitesi Sosyal Bilimler Enstitüsü, Adana.

Ashfaq, A., \& Ramzan, M. (2013). Effects of job stress on employees job performance a study on banking sector of Pakistan, IOSR Journal of Business and Management, 11(6), 61-68.

Avey, J. B., Luthans, F., \& Youssef, C. M. (2010). The additive value of positive psychological capital in predicting work attitudes and behaviors. Journal of Management, 36(2), 430-452.

https://doi.org/10.1177/0149206308329961

Bandura, A. (1997). Self-efficacy: The exercise of control. New York, NY: W. H. Freeman.

Basım, H. N., \& Begenirbaş, M. (2012). Çalışma yaşamında duygusal emek: Bir ölçek uyarlama çalışması [Emotional labor in work life: A study of scale adaptation]. Celal Bayar Üniversitesi Iktisadi ve İdari Bilimler Fakültesi Yönetim ve Ekonomi Dergisi, 19(1), 77-90.

Begenirbaş, M., \& Çalışkan, A. (2014). Duygusal emeğin iş performansı ve işten ayrılma niyetine etkisinde kişilerarası çarpıklığın aracılık rolü [The mediating role of interpersonal deviance on effects of emotional labor to job performance and intention to quit], Business and Economics Research Journal, 5(2), 109-127.

Bickes, D. M., Yılmaz, C., Demirtaş, Ö., \& Uğur, A. (2014). Duygusal emek ile iş tatmini arasındaki ilişkide psikolojik sermayenin aracılık rolü: Bir alan çalışması [The mediating role of psychological capital on the relationship between emotional labor and job satisfaction: A field study], Eskişehir Osmangazi Üniversitesi İktisadi ve İdari Bilimler Dergisi, 9(2), 97-121.

Bolton, S. C. (2005). Emotion management in the workplace. Palgrave Macmilan.

Borman, W. C., \& Motowidlo, S. J. (1993). Expanding the criterion domain to include elements of contextual performance. personnel selection in organizations. New York, NY: Jossey-Bass.

Bouzari, M., \& Karatepe, O. M. (2016). Test of a mediation model of psychological capital among hotel salespeople, International Journal of Contemporary Hospitality Management, 29(8), 2178-2197.

https://doi.org/10.1108/IJCHM-01-2016-0022

Brotheridge, C. M., \& Grandey, A. A. (2002). Emotional labor and burnout: Comparing two perspectives of "people work", Journal of Vocational Behavior, 60(1), 17-39.

https://psycnet.apa.org/doi/10.1006/jvbe.2001.1815

Büyükbeşe, T., \& Aslan, H. (2019). Psikolojik sermaye ve duygusal emeğin örgütsel bağl1lık üzerindeki etkisi [The effect of psychological capital and emotional labor on organizational commitment], Işletme Araştırmaları Dergisi, 11(2), 949-963.

https://doi.org/10.20491/isarder.2019.647

Chu, K. L., \& Murrmann, S. K. (2006). Development and validation of the hospitality emotional labor scale, Tourism Management, 27(6), 1181-1191.

https://doi.org/10.1016/j.tourman.2005.12.011 
Çağlıyan, V., Fındık, M., \& Doğanalp, B. (2013). A consideration on emotional labour, burnout syndrome and job performance: The case of health institutions, Mediterranean Journal of Social Sciences, 4(10), $532-540$.

http://dx.doi.org/10.5901/mjss.2013.v4n10p532

Çelik, M., \& Bilginer, F. G. (2018). Psikolojik sermayenin iş tatmini üzerine etkisinde lidere duyulan güvenin aracılık rolü: Turizm sektöründe bir araştırma [The role of trust in leader in the effect of psychological capital on job satisfaction: A research in tourism sector], Süleyman Demirel Üniversitesi Sosyal Bilimler Enstitüsü Dergisi, 2(31), 138-160.

Çelik, M., \& Yıldız, B. (2016). Duygusal emek düzeyinin işten ayrılma niyeti üzerindeki etkisinde stresin aracilık rolü [The moderating role of stress on the affect of emotional labour level on intention to quit], Uluslararası Sosyal Araştırmalar Dergisi, 9(45), 734-745.

http://dx.doi.org/10.17719/jisr.20164520651

Çolak, N. (2018). Duygusal emeğin iş performansına etkisi: Havacılık sektöründe bir uygulama. (Doktora Tezi). Maltepe Üniversitesi Sosyal Bilimler Enstitüsü, İstanbul.

Dahiya, A. (2017). Extroversion and emotional labour: A study on organized retail sector, International Journal of Research in Commerce and Management, 8(4), 50-54.

Demir, M., \& Şen Demir Ş. (2019). The effects of psychological capital on employees' organizational identification in hotels. Journal of Tourism Theory and Research, 5(3), 355-369.

https://doi.org/10.24288/jttr.573851

Demirel, N. (2015). Duygusal emek faktörünün hizmet kalitesine etkisi: Nevşehir'deki dört ve beş yıldızlı otellere yönelik bir araştırma. (Yüksek Lisans Tezi). Nevşehir Hacı Bektaş Veli Üniversitesi Sosyal Bilimler Enstitüsü, Nevşehir.

Diefendorff, J. M., Croyle, M. H., \& Gosserand, R. H. (2005). The dimensionality and antecedents of emotional labor strategies, Journal of Organizational Behavior, 66, 339-357.

https://doi.org/10.1016/j.jvb.2004.02.001

Dönmez, B. (2014). Pozitif psikolojik sermaye ile işe ilişkin duyuşsal algısı, iş doyumu, işgören performansı ve yaşam doyumu ilişkilerinin seyahat acentesi çalışanları örnekleminde incelenmesi, (Doktora Tezi), Mersin Üniversitesi Sosyal Bilimler Enstitüsü, Mersin.

Duran, E., \& Gümüş, M. (2013). Turizm lisans öğrencilerinin duygusal emek deneyimlerinin kariyer tercihlerine etkileri [Effects of tourism undergraduate students' emotional labor experiences on their career preferences]. Dokuz Eylül Üniversitesi Sosyal Bilimler Enstitüsü Dergisi, 15(2), 233-251.

Erkuş, A., \& Afacan Fındıklı, M. (2013). Psikolojik sermayenin iş tatmini, iş performansı ve işten ayrılma niyeti üzerindeki etkisine yönelik bir araştırma [A research on the impact of psychological capital to job satisfaction, job performance and intention to quit]. İstanbul Üniversitesi İsletme Fakültesi Dergisi, 42(2), 302-318.

Eroğlu, Ş. G. (2014). Örgütlerde duygusal emek ve tükenmişlik üzerine bir araştırma [A research on the relation between emotional labor and burnout in organizations]. Pamukkale Üniversitesi Sosyal Bilimler Enstitüsü Dergisi, 19, 147-160.

Eşitti, B. (2015, Kasım). Konaklama sektöründe algılanan birey-örgüt uyumu, duygusal emek ve iş performansı ilişkisinin yapısal eşitlik modeli ile incelenmesi. 16. Ulusal Turizm Kongresi Bildiriler Kitabı, Çanakkale.

Fredrickson, B. L. (2001). The role of positive emotions in positive psychology: The broaden and build theory of positive emotions, American Psychologist, 56, 218-226. 
Fredrickson, B. L., \& Losada, M. F. (2005). Positive affect and the complex dynamics of human flourishing, American Psychologist, 60(7), 678-686.

https://dx.doi.org/10.1037\%2F0003-066X.60.7.678

Furnell, B. A. (2008). Exploring the relationship between burnout, emotional labour and emotional intelligence: A study on call-centre representatives. (Master's thesis), University of Stellenbosch, Stellenbosch.

Gabriel, A. S., \& Diefendorff, J. M. (2015). Emotional labor dynamics: A momentary approach, Academy of Management Journal, 58(6), 1804-1825.

http://dx.doi.org/10.5465/amj.2013.1135

Genç, V., \& Gümüş, M. (2017). Otel işletmelerinde iş tatmininin arttırılması: Çalışanların duygusal zekaları ve duygusal emeklerinin rolü [The improvement of job satisfaction in hotel establishments: The role of emotional intelligence and emotional labor of employee]. Journal of Recreation and Tourism Research, 4(4), 43-52.

George, J. M., \& Jones, G. R. (2005). Understanding and managing organizational behavior (4th ed.). New Jersey: NY: Pearson Education Inc.

Giardini, A., \& Frese, M. (2006). Reducing the negative effects of emotion work in service occupations: Emotional competence as a psychological resource, Journal of Occupational Health Psychology, 11, 63-75.

http://dx.doi.org/10.1037/1076-8998.11.1.63

Goodwin, R. E., Groth, M., \& Frenkel, S. (2011). Relationships between emotional labor, job performance, and turnover, Journal of Vocational Behaviour, 79(2), 538-548.

https://doi.org/10.1016/j.jvb.2011.03.001

Grandey, A. A. (2000). Emotion regulation in the workplace: A new way to conceptualize emotional labor. Journal of Occupational Health Psychology, 5(1), 95-110.

http://dx.doi.org/10.1037//1076-8998.5.1.95

Grandey, A. A. (2003). When "the show must go on": Surface acting and deep acting as determinants of emotional exhaustion and peer-rated service delivery, Academy of Management Journal, 46(1), 86-96. https://doi.org/10.5465/30040678

Grandey, A. A., Fisk, G. M., Mattila, A. S., Jansen, K. J., \& Sideman, L. A. (2005). Is "service with a smile" enough? Authenticity of positive displays during service encounters. Organizational Behavior and Human Decision Processes, 96, 38-55.

https://doi.org/10.1016/j.obhdp.2004.08.002

Hırlak, B., Taşlıyan, M., \& Sezer, B. (2017). İyimserlik ve yaşam doyumu arasındaki ilişki, demografik özellikler bağlamında algı farklılıkları: Bir alan araştırması [The relationship between optimism and life satisfaction, perception differences in the context of demographic characteristics: An empirical study]. Kahramanmaraş Sütçü İmam Üniversitesi İktisadi ve İdari Bilimler Fakültesi Dergisi, 7(1), 95-116.

Hochschild, A. R. (1983/2012). The managed heart: Commercialization of human feeling. Berkeley, University of California Press.

Hodges, H. F., Keeley, A. C., \& Grier, E. C. (2005). Professional resilience, practice longevity and Parse's theory for baccalaureate education, Journal of Nursing Education, 44, 548-554.

https://doi.org/10.3928/01484834-20051201-04

Humphrey, R. H., Ashforth, B. E., \& Diefendorff, J. M. (2015). The bright side of emotional labor. Journal of Organizational Behavior, 36(6), 749-769.

http://dx.doi.org/10.1002/job.2019 
Hur, W. M., Rhee, S. Y., \& Ahn, K. H. (2016). Positive psychological capital and emotional labor in Korea: The job demands-resources approach. The International Journal of Human Resource Management, 27(5), 477-500.

https://doi.org/10.1080/09585192.2015.1020445

Jackson, D., Firtko, A., \& Edenborough, M. (2007). Personal resilience as a strategy for surviving and thriving in the face of workplace adversity: A literature review. Journal of Advanced Nursing, 60(1), 1-9. https://doi.org/10.1111/j.1365-2648.2007.04412.x

Jung, H. S., \& Yoon, H. H. Y. (2015). The impact of employees' positive psychological capital on job satisfaction and organizational citizenship behaviors in the hotel. International Journal of Contemporary Hospitality Management, 27(6), 1135-1156.

http://dx.doi.org/10.1108/IJCHM-01-2014-0019

Kaplan, M., \& Ulutaş, Ö. (2016). Duygusal emeğin tükenmişlik üzerindeki etkisi: Otel işletmelerinde bir araştırma [The effect of emotional labour on burnout: A case of study in hotel businesses]. Selçuk Üniversitesi Sosyal Bilimler Enstitüsü Dergisi, 35, 165-174.

Karakaş, A. (2017). Duygusal emek, tükenmişlik ve işten ayrılma niyeti arasındaki ilişki: Otel işletmesi çalışanları üzerine bir araştırma [Relationship between emotional labor, burnout and turnover intention: A study on hotel business employees]. Işsletme Araştırmaları Dergisi, 9(1), 80-112.

http://dx.doi.org/10.20491/isarder.2017.236

Karakurum, M. (2005). The effects of person-organization fit on employee job satisfaction, performance and organizational commitment in a Turkish public organization. (Doktora tezi), Orta Doğu Teknik Üniversitesi Sosyal Bilimler Enstitüsü, Ankara.

Karatepe, O. M. (2014). Hope, work engagement, and organizationally valued performance outcomes: An empirical study in the hotel industry. Journal of Hospitality Marketing and Management, 23(6), 678-698. http://dx.doi.org/10.1080/19368623.2014.855994

Kaya, I., Atabay, I., \& Alamur, B. (2017). The relationship between psychological capital and emotional labor behaviors of employee in tourism sector. Global Business Research Congress, 3, 522-532.

https://doi.org/10.17261/Pressacademia.2017.627

Kızanıklı, M., \& Çöp, S. (2017). Otel işletmesi çalışanlarında pozitif psikolojik sermaye ile iş performansı algısı arasındaki ilişki [The relationship between positive psychological capital and job performance perception on hotel employees]. Journal of Tourism and Gastronomy Studies, 5(3), 268-287.

http://dx.doi.org/10.21325/jotags.2017.94

Kim, M., Perrewe P. L., Kim, Y. K., \& Kim, A. C. H. (2017). Psychological capital in sport organizations: Hope, efficacy, resilience, and optimism among employees in sport. European Sport Management Quarterly, 17(5), 659-680.

http://dx.doi.org/10.1080/16184742.2017.1344284

Ko, C. H., \& Jeng, S. N. (2016). Exploring the effects of emotional labor in the hotel industry. The International Journal of Organizational Innovation, 9(2), 158-167.

Kodaş, B. (2018), Psikolojik sermaye, iş stresi ve hizmet odaklı örgütsel vatandaşlık davranışı ilişkisi: Yiyecek içecek çalışanları örneği. (Doktora Tezi). Eskişehir Osmangazi Üniversitesi Sosyal Bilimler Enstitüsü, Eskişehir. 
Kumlu, T., \& Güçlü Nergiz, H. (2018). Otel işletmesi çalışanlarının pozitif psikolojik sermaye düzeyleri ile örgütsel vatandaşlık davranışları arasındaki ilişki [Relatıionship between levels of positive psychological capital and organizational citizenship behaviors on hotel employees]. Uluslararası Turizm ve Sosyal Araştırmalar Dergisi, 3, 1-13.

Kurt, T. (2012). Öğretmenlerin öz-yeterlilik ve kolektif yeterlilik algıları [Self-effıcacy and collective-efficacy perceptions of teachers]. Türk Ĕ̈itim Bilimleri Dergisi, 10(2), 195-227. Retrieved from https:// dergipark.org.tr/tr/pub/tebd/issue/26137/275278

Lin, T. L. (2013). The relationships among perceived organization support, psychological capital and employees' job burnout in international tourist hotels. Life Science Journal, 10(3), 2104-2112.

Lu, C., Shih, Y., \& Chen, Y. (2013). Effects of emotional labor and job satisfaction on organizational citizenship behaviors: A case study on business hotel chains, The International Journal of Organizational Innovation, 5(4), 165-176.

Luthans, F., Avey, J. B., Avolio, B. J., Norman, S. M., \& Combs, G. M. (2006). Psychological capital development: Toward a micro intervention. Journal Of Organizational Behaviour, 27, 387-393.

http://dx.doi.org/10.1002/job.373

Luthans, F., Luthans, K. W., \& Luthans, B. C. (2004). Positive psychological capital: Beyond human and social capital. Business Horizons, 47(1), 45-50.

https://doi.org/10.1016/j.bushor.2003.11.007

Luthans, F., Norman, S. M., Avolio, B. J., \& Avey, J. B. (2008). The mediating role of psychological capital in the supportive organizational climate-employee performance relationship. Journal of Organizational Behavior, 29, 219-238.

https://psycnet.apa.org/doi/10.1002/job.507

Luthans, F., Youssef, C. M., \& Avolio, B. J. (2007). Psychological capital: Developing the human competitive edge. Oxford, UK: Oxford University Press.

Miranda, M., \& Godwin, M. L. (2018). Emotional labor beyond the frontlines: Work settings, interactions, and coping strategies. Administrative Theory and Praxis, 40, 320-341.

https://doi.org/10.1080/10841806.2018.1485450

Murphy, K. R. (1989). Is the relationship between cognitive ability and job performance stable over time? Human Performance, 10(2), 183-200. https://doi.org/10.1207/s15327043hup0203_3

Nasurdin, A. M., Ling, T. C., \& Sabrina, N. K. (2018). The role of psychological capital on nursing performance in the context of medical tourism in Malaysia. International Journal of Business and Society, 19(3), 748-761.

Oral, L., \& Köse, S. (2011). Hekimlerin duygusal emek kullanımı ile iş doyumu ve tükenmişlik düzeyleri arasındaki ilişkiler üzerine bir araştırma [A research on phsicians' use of emotional labor and the relationship between their job satisfaction and burnout levels]. Süleyman Demirel Üniversitesi Iktisadi ve İdari Bilimler Fakültesi Dergisi, 16(2), 463-492. Retrieved from https://dergipark.org.tr/tr/pub/sduiibfd/ issue/20824/222952

Özdamar, K. (2001). Spss ile biyoistatistik. Eskişehir: Kaan Kitabevi.

Özyılmaz Misican, D., \& Türkoğlu, N. (2019). Psikolojik sermayenin duygusal emek üzerine etkisi: Hizmet sektöründe bir araştırma [Impact of psychological capital on emotional labor: A research on service sector]. Işsletme Araştırmaları Dergisi, 11(1), 173-188.

http://dx.doi.org/10.20491/isarder.2019.591 
Paek, S., Schuckert, M., Kim, T. T., \& Lee, G. (2015). Why is hospitality employees' psychological capital important? The effects of psychological capital on work engagement and employee morale. International Journal of Hospitality Management, 50, 9-26.

https://doi.org/10.1016/j.ijhm.2015.07.001

Pala, T., \& Tepeci, M. (2014). Otel işletmelerinde çalışanların duygusal emek boyutlarının belirlenmesi ve duygusal emek boyutlarının iş tatmini ve işte kalma niyeti üzerine etkisi [The dimensions and effects of emotional labor on employee job satisfaction and intention to stay in hotels]. Seyahat ve Otel Işsletmeciliği Dergisi, 11(1), 21-37. Retrieved from https://dergipark.org.tr/tr/pub/soid/issue/11357/135816

Peterson, S. J., Luthans, F., Avolio, B. J., Walumbwa, F. O., \& Zhang, Z. (2011). Psychological capital and employee performance: A latent growth modeling approach. Personnel Psychology, 64(2), 427-450. http://dx.doi.org/10.1111/j.1744-6570.2011.01215.x

Pugliesi, K. (1999). The consequences of emotional labor: Effects on work stress, job satisfaction, and wellbeing, Motivation and Emotion, 23(2), 125-154.

http://dx.doi.org/10.1023/A:1021329112679

Rezaee, A., Khoshsima, H., Zare Bahtash, E., \& Sarani, A. (2018). A mixed method study of the relationship between teachers' job satisfaction and job performance in Iran. International Journal of Instruction, 11(4), 391-408.

http://dx.doi.org/10.12973/iji.2018.11425a

Rich, G. A. (1999). Salesperson optimism: Can sales managers enhance it and so what if they do?. Journal of Marketing Theory and Practice, 7(1), 53-63.

https://doi.org/10.1080/10696679.1999.11501819

Robbins, S. P., \& Judge, T. A. (2013). Örgütsel davranış (14.bs) (İ. Erdem, Çev.). İstanbul: Nobel Yayın.

Safavi, H. P., \& Bouzari, M. (2019). The association of psychological capital, career adaptability and career competency among hotel frontline employees,. Tourism Management Perspectives, 30, 65-74. http://dx.doi.org/10.1016/j.tmp.2019.02.001

Saithong-in, S. (2016). Psychological capital and job performance: An empirical research of certified public accountants (cpas) in Thailand. The Business and Management Review. 7, 499-506.

Santos, E. F., \& Fontenelle, I. A. (2019). The construction of meaning for the emotional labor. Human and Social Management, 20(1), 1-26.

https://doi.org/10.1590/1678-6971/eRAMG190089

Scott, B. A., \& Barnes, C. M. (2011). A multilevel field investigation of emotional labor, affect, work withdrawal, and gender. Academy of Management Journal, 54(1), 116-136.

http://dx.doi.org/10.5465/AMJ.2011.59215086

Seligman M. E. P. (2011). Flourish: A visionary new understanding of happiness and well being. New York, NY: Free Press.

Seligman, M. E. P., \& Csikszentmihalyi, M. (2014). Positive psychology: An introduction. Heidelberg, H: Springer Netherlands.

Shahnawaz, M. G., \& Jafri, H. (2009). Job attitudes as predictor of employee turnover among stayers and leavers/hoppers. Journal of Management Research, 9(3), 159-166.

Shapoval, V. (2019). Organizational injustice and emotional labor of hotel front-line employees. International Journal of Hospitality Management, 78, 112-121.

https://doi.org/10.1016/j.ijhm.2018.10.022 
Sohn, H. K., \& Lee, T. J. (2012). Relationship between hexaco personality factors and emotional labour of service providers in the tourism industry. Tourism Management, 33(1), 116-125.

http://dx.doi.org/10.1016/j.tourman.2011.02.010

Sun, T., Zhao, X. W., Yang, L. B., \& Fan, L. H. (2012). The impact of psychological capital on job embeddedness and job performance among nurses: A structural equation approach. Journal of Advanced Nursing, 68(1), 69-79.

https://doi.org/10.1111/j.1365-2648.2011.05715.x

Suna, B., \& Okun, O. (2019). Otel çalışanlarının psikolojik sermaye düzeylerinin yenilikçi düşünce yapısına etkisi: Van ili örneği [The effect of psychological capital levels on innovative thinking structure of the employees working in hotel enterprises: The case of Van Province]. I $\breve{g} d \imath$ Üniversitesi Sosyal Bilimler Dergisi, 19, 491-518.

Tice, D. M., \& Bratslavsky, E. (2000). Given in to feel good: the place of emotion regulation in the context of general self control. Psychological Inquiry, 11(3), 149-159.

https://doi.org/10.1207/S15327965PLI1103_03

Tokmak, İ. (2014). Duygusal emek ile işe yabancılaşma ilişkisinde psikolojik sermayenin düzenleyici etkisi [The moderating effect of psychological capital in the relation between emotional labor and work alienation]. Iş̧letme Araştırmaları Dergisi, 6 (3), 134-156.

Tsai, W. C. (2001). Determinants and consequences of employee displayed positive emotions. Journal of Management, 27, 497-512.

https://doi.org/10.1177\%2F014920630102700406

Tüzün, İ. K., Çetin, F., \& Basım, H. N. (2014). The role of psychological capital and supportive organizational practices in the turnover process. METU Studies in Development, 41(2), 85-103.

Ünlü, O., \& Yürür, S. (2011). Duygusal emek, duygusal tükenme ve görev/ bağlamsal performans ilişkisi: Yalova'da hizmet sektörü çalışanları ile bir araştırma [The relationship among emotional labor, emotional exhaustion and task/contextual performance: A study with service industry workers at Yalova], Erciyes Üniversitesi İktisadi ve İdari Bilimler Fakültesi Dergisi, 37, 183-207.

Wang, Y., Mei, J., \& Zhu, J. (2017). Linking psychological capital and feedback-seeking behavior: Feedback cognition as a mediator. Social Behavior and Personality, 45(7), 1099-1112.

http://dx.doi.org/10.2224/sbp.6055

Weiss, H. M., \& Cropanzano, R. (1996). Affective events theory: A theoretical discussion of the structure, causes and consequences of affective experiences at work. Research in Organizational Behavior, 18(1), $1-79$.

Wen, J., Huang, S., \& Hou, P. (2019). Emotional intelligence, emotional labor, perceived organizational support, and job satisfaction: A moderated mediation model. International Journal of Hospitality Management, 81, 120-130.

https://doi.org/10.1016/j.ijhm.2019.01.009

Wharton, A. S., \& Erickson, R. J. (1993). Managing emotions on the job and at home: Understanding the consequences of multiple emotional roles. Academy of Management Review, 18, 457-486.

http://dx.doi.org/10.2307/258905

Yakar, S. (2015). Turizm işletmelerinde duygusal emek ve tükenmişlik ilişkisi: Otel işletmelerine yönelik bir araştırma. (Yüksek Lisans Tezi). Dokuz Eylül Üniversitesi Sosyal Bilimler Enstitüsü, İzmir. 
Yorulmaz, F., \& Yavan, Ö. (2018). Pozitif psikolojik sermayenin işveren marka oluşumu üzerindeki etkisi: Turizm sektörü örneği [The effects of psychological capital on the employer branding: Tourism sector example]. Atatürk Üniversitesi Sosyal Bilimler Enstitüsü Dergisi, 22(2), 1007-1027. Retrieved from https://dergipark.org.tr/tr/pub/ataunisosbil/issue/37826/424714

Yücebalkan, B., \& Karasakal, N. (2016). Akademisyenlerde duygusal emek ile tükenmişlik düzeyi arasındaki ilişkiye yönelik bir araştırma: Kocaeli Üniversitesi örneği [A study on the relationship between emotional labor behavior and burnout level of academics: Kocaeli University sample], Uluslararası Bilimsel Araştırmalar Dergisi, 1(2), 187-200.

http://doi.org/10.21733/ibad.26

Yücel, E. (2019). Pozitif psikolojik sermayenin iş tatminine etkisi: Turizm sektöründe bir araştırma [The effect of positive psychological capital on work satisfaction: A research in tourism sector]. Business and Management Studies: An International Journal, 7 (4), 1136-1154.

http://dx.doi.org/10.15295/bmij.v7i4.1213

Zeb, A., Abdullah, N. H., Bin Othayman, M., \& Ali, M. (2019). The role of imx in explaining relationships between organizational justice and job performance. Journal of Competitiveness, 11(2), 144-160.

http://dx.doi.org/10.1111/j.1365-2648.2010.05281.x 
